\title{
An Epidemiologic and Economic Study of Respiratory Diseases in Two Conventional Danish Swine Herds. II: Associations Between Lesions Present at Slaughter and Mean Daily Gains During Specific Intervals of the Growth Period
}

\author{
By L.G. Paisley, L. Vraa-Andersen, L. Dybkjar, K. Møller, G. Christensen, J. Mousing and \\ J. F. Agger
}

Department of Anımal Science and Animal Health, Division of Ethology and Health, Royal Veterinary and Agricultural University, Frederiksberg, and The Federation of Danish Pig Producers and Slaughterhouses, Kjellerup and Copenhagen, Denmark.

\begin{abstract}
Paisley, L.G., L. Vraa-Andersen, L. Dybkjar, K. Møller, G. Christensen, J. Mousing and J.F. Agger: An epidemiologic and economic study of respiratory diseases in two conventional danish swine herds. II: Associations between lesions present at slaughter and mean daily gains during specific intervals of the growth period. Acta vet. scand. 1993, 34, 331-344. - A total of 578 slaughter pigs from 2 Danısh conventional farrowto-finish operations (Herds a and B) were followed from an age of 14 days to slaughter. Pigs were weighed at 3 weeks intervals and at slaughter and extended post mortem examination of the plucks was done. Regression models with second and third order interaction terms demonstrated that Mycoplasma-like pneumonia, complicated pneumonia, anterio-ventral pleuritıs, pericarditis, fissures and atrophic rhinitis, separately and through interactions with other lesions, significantly reduced mean dally gains during specific intervals of the growth period in 2 conventional swine herds. It is likely that the periods of reduced growth reflect the times when the diseases were in the acute and early recovery stages. Maxımum estimated reductions in daily gains associated with the combined lesions were 82 grams and 283 grams during the interval 120-140 days in Herds A and B, respectively. Although dorso-caudal pleuritis and parietal pleuritis had minor negatıve effects durıng 2 intervals neither had a significant adverse effect on total growth rate in either herd (Paisley et al. 1993). $\mathbf{R}^{2}$ values for the regression models were less than 0.27 showing that the lesions present at slaughter explained less than $27 \%$ of the vanation in herd mean daily gains during any interval.
\end{abstract}

pneumonia; pleuritis; atrophic rhinitis; pericarditis; interactions.

\section{Introduction}

Respiratory diseases cause losses to the swine industry via mortalities, decreased growth rates, reduced feed conversion efficiency, re- duced carcass quality, condemnations, and expenditures for therapy and prevention (Lindqvist 1974, Aalund et al. 1976, Christensen 1982, Straw et al. 1983, Friendship et al. 
1984, Rasmussen 1984, Pointon et al. 1985, Straw et al. 1985, Derosiers \& Moore 1986, Baalsrud 1987, Paisley 1991, Paisley et al. 1993). In Denmark, pneumonia and chronic pleuritis account for about $67 \%$ of the lesions reported at slaughter (Willeberg et al. 1982). Mycoplasma hyopneumoniae and Actinobacillus pleuropneumoniae, serotype 2 are the infectious agents most often associated with these lesions (Willeberg et al. 1982, Mousing et al. 1989).

The economic impacts of respiratory diseases are not easy to clarify because the results of existing studies are not consistent. Some, if not most, studies have shown negative effects of pneumonia, and chronic pleuritis on some production parameters. Straw et al. (1989), reviewed 27 studies in which the effects of pneumonia on growth rate and feed utilization efficiency were measured. In 13 reports on pigs with Mycoplasma pneumonia, the decreases in mean daily gains ranged from $2.76 \%$ to $44.07 \%$ and the decreases in feed efficiency ranged from $-2.40 \%$ to $44.07 \%$. Pigs with $A c$ tinobacillus pleuropneumonia were compared to unaffected pigs in 14 studies. The decreases in mean daily gains ranged from $-3.57 \%$ to $76.77 \%$ and the decreases in feed efficiency ranged from $-6.91 \%$ to $60.90 \%$. The authors suggested that, on the average, each $10 \%$ of lung affected by either type of pneumonia reduced mean daily gains by 37.4 grams.

The reported effects of atrophic rhinitis also vary between studies. Some have reported reduced growth rates or feed efficiency (Pedersen \& Barfod 1981, Bäckstrom et al. 1985, Baalsrud 1987, Cowart et al. 1990) and others have reported no negative effects (Straw et al. 1983, Straw et al. 1985, Love et al. 1985, Scheit et al. 1990).

Paisley et al. (1993) reported that Mycoplasma pneumonia, complicated pneumonia, anterio-ventral pleuritis, fissures, and atroph- ic rhinitis were associated with decreased mean daily gains during the interval from approximately 14 days of age until slaughter. The decreases were $4.8 \%$ in 1 and $15.1 \%$ in another conventional, Danish farrow-to-finish herd.

The objective of this study was to determine if specific intervals when lesions and interactions between lesions exerted their effects on growth could be identified. This may result in a better understanding of the differences in the effects on growth rates that lesions present at slaughter exerted in the 2 herds (Paisley et al. 1993).

\section{Materials and methods}

The study design has been described in detail (Paisley et al. 1993, Dybkjar et. al 1993). Briefly, the sample consisted of 654 pigs from 2 conventional, farrow to finish piggeries located on the island Sealand, Denmark. The herds were selected primarily because of high prevalences of chronic pleuritis in their slaughter swine. Herd A maintains 800-1000 sows, markets approximately 20,000 pigs annually and has an all-in-all-out management system. Herd B maintains about 140 sows and markets about 3,300 pigs annually. In this herd there is continual mixing of pigs of different ages in the growing and finishing units. Boars are castrated during the first week on Farm A but not on Farm B. Both farms vaccinated the sows against atrophic rhinitis but not other respiratory diseases. Ad libitum feeding was used in the controlled environment housing while the amount and blend of feed was computerized in the growing and fattening barns. Both farms had computerized production monitoring and feeding systems.

Entire litters of piglets entered the study at 14 \pm 6 days of age. They were positively identified, bled and weighed at entry and at 21 day 
intervals until they were 20 weeks old. The live-weight at slaughter was estimated from the carcass weight (Kjeldsen et al. 1990). The thoracic organs of every pig that was slaughtered underwent an extensive digital and visual examination by the same veterinarian (Christensen 1991). The type of lesion, the location and percentage of lung or other organ affected were recorded on diagrams. The snouts were sectioned and mean turbinate perimeter ratios (MTPR) were calculated (Collins et al. 1989).

\section{Statistical analysis}

The lesions were coded as present " 1 ", or absent " 0 " or used as continuous variables based on the percentage of the total lung surface or parenchyma affected. Atrophic rhinitis scores ( $\mathrm{AR}=0, \mathrm{AR}=1, \mathrm{AR}=2, \mathrm{AR}=3$ ) were assigned, based on the mean turbinate perimeter ratios (Collins et al. 1989, Paisley 1991).

Mean daily gains during each 21 day interval and the interval from the seventh weighing until slaughter were regressed against the lesions by backward, stepwise, multiple linear regression (SAS Institute Inc. 1988). To remain in the model the coefficient of a dependent variable needed a $p$-value $\leq 0.05$.

The intercepts of the regression equations were used as estimates of the herd mean daily gains when all lesions were equal to " 0 " i.e, the mean daily gain of the "no-lesion" or control group. From these equations the total impact of the lesions on mean daily gains was estimated by subtracting the actual herd mean daily gain for an interval from the intercept for that interval. The difference in mean daily gain associated with individual lesions was estimated by multiplying the coefficient of a lesion by the percentage of lung affected.

The saturated regression model included up to third order interaction terms and was of the general form:

$$
\begin{aligned}
\mathrm{MDG}_{1}= & \alpha_{0}+\beta_{1} \mathrm{~S}+\beta_{2} \mathrm{~A}+\beta_{3} \mathrm{~B}+\beta_{4} \mathrm{C}+\beta_{5} \mathrm{D} \\
& +\beta_{6} \mathrm{E}+\beta_{7} \mathrm{~F}+\beta_{8} \mathrm{G}+\beta_{9} \mathrm{H}+\gamma_{1} \mathrm{~A} \times \mathrm{B} \\
& +\delta_{1} \mathrm{~A} \times \mathrm{B} \times \mathrm{C} \ldots
\end{aligned}
$$

For abbreviations please see Paisley et al. (1993).

Standard microcomputer software (SAS Institute Inc. 1988) was used to tabulate data and to do statistical procedures.

\section{Results}

Slaughter data was obtained for 593 of the 654 pigs that were included in the study. The results are based on 283 pigs from Herd A and 295 from Herd B that had complete data.

Table 1 contains some descriptive statistics for the 2 cohorts. The mean daily gains from 14 days until slaughter (MDG14) and from $25 \mathrm{~kg}$ until slaughter (MDG25) were not significantly different between the 2 herds but the mean slaughter age (SLAGE) and slaughter weights of Herd A pigs were significantly higher than in Herd B. There were significant differences in the mean daily gains between

Tabel 1. Descriptive statistics of mean daily gain and age of slaughter in herds A and B.

\begin{tabular}{lcccl}
\hline & & Herd A & Herd B & P value $^{1}$ \\
\hline TOTAL no og pigs & 283 & 295 & \\
& & & & \\
MDG1 & grams/day & 174 & 177 & 0.5 \\
MDG2 & $"$ & 333 & 441 & 0.0001 \\
MDG3 & $"$ & 469 & 450 & 0.11 \\
MDG4 & $\#$ & 462 & 571 & 0.0001 \\
MDG5 & $\#$ & 658 & 660 & 0.9 \\
MDG6 & $"$ & 807 & 654 & 0.0001 \\
MDG7 & $"$ & 678 & 640 & 0.7 \\
MDG14 & $"$ & 530 & 530 & 0.7 \\
MDG25 & 659 & 646 & 0.8 \\
SLAGE days & 181.72 & 175.85 & 0.0001 \\
\hline
\end{tabular}

1) Differences between the herds were tested with the t-test.

MDG = Mean daily gain.

SLAGE = Age of slaughter. 


\section{MEAN DAILY GAINS \\ LESION VB NO LESION - HERD A}

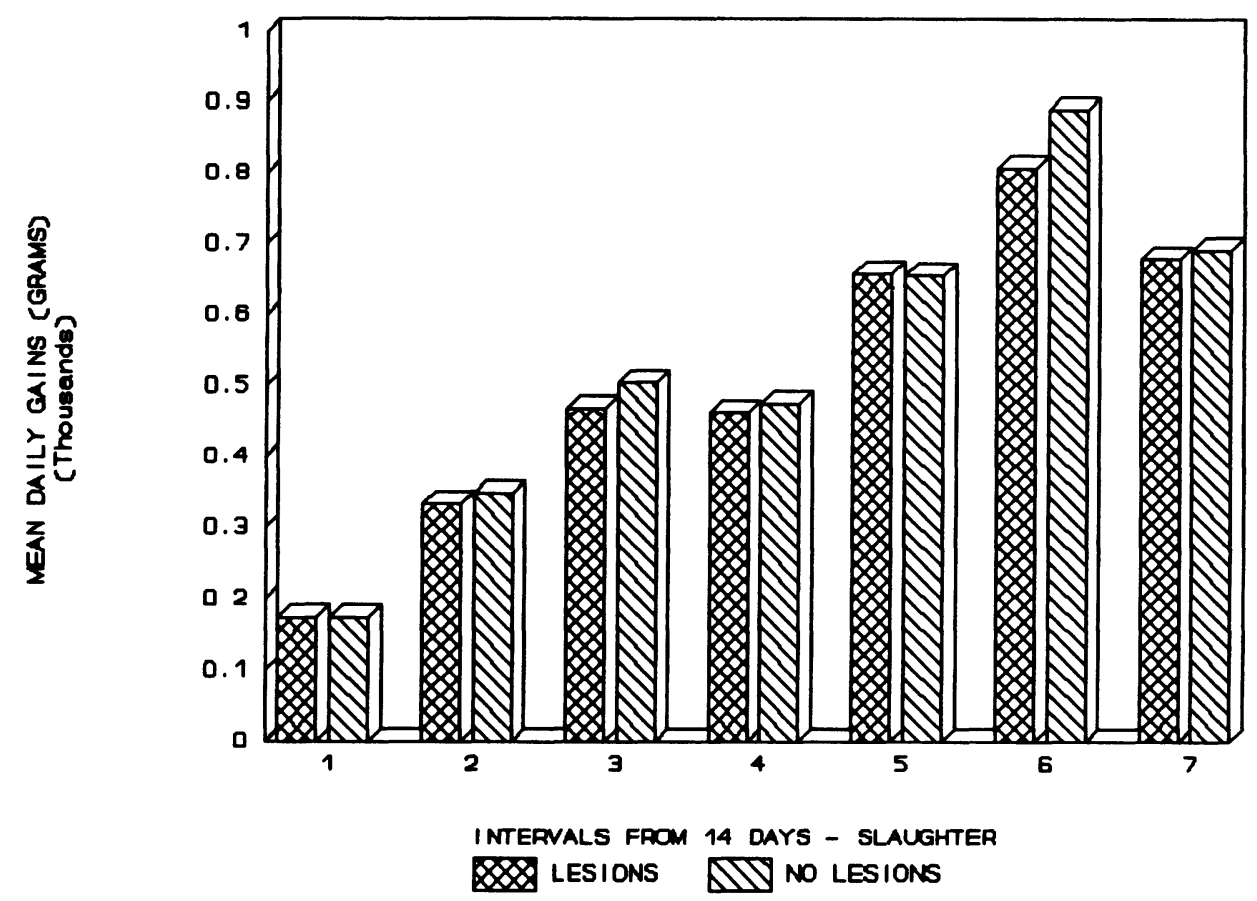

Figu re 1. This graph compares the recorded mean dally gains of the pigs in Herd A with those estımated had there been no lesion effects. The estimated mean dally gains were the intercepts when the herd mean daily gain for each interval was regressed against the lesions present at slaughter.

the herds during the second, fourth and sixth intervals.

Both herds had high prevalences of thoracic lesions. Only $7.5 \%$ and $1.3 \%$ of the pigs in Herds A and B, respectively, lacked lesions. Herd B had significantly more pigs with the various types of lesions than Herd A. The mean percentages of lung affected by the various lesions were generally higher in Herd B and more pigs had multiple lesions (Paisley et al. 1993).

For each interval the difference between the intercept of the final model and the mean daily gain of the herd was interpreted as the difference in mean daily gain associated with lesions present at slaughter. Fig. 1 and 2 illustrate the differences in mean daily gains associated with lesions present at slaughter in Herds A and B, respectively. None of the 3-way interactions were significant.

\section{Herd A}

In Herd A, none of the lesions were associated with mean daily gains during the first interval, 14-35 days. During the second interval, 35-56 days, anterio-ventral pleuritis, CPAV, $(p=0.0244)$ and parietal pleuritis, CPPL, $(p=0.037)$ were associated with de- 


\section{MEAN DAILY GAINS \\ LESION VB NO LESION - HERD B}

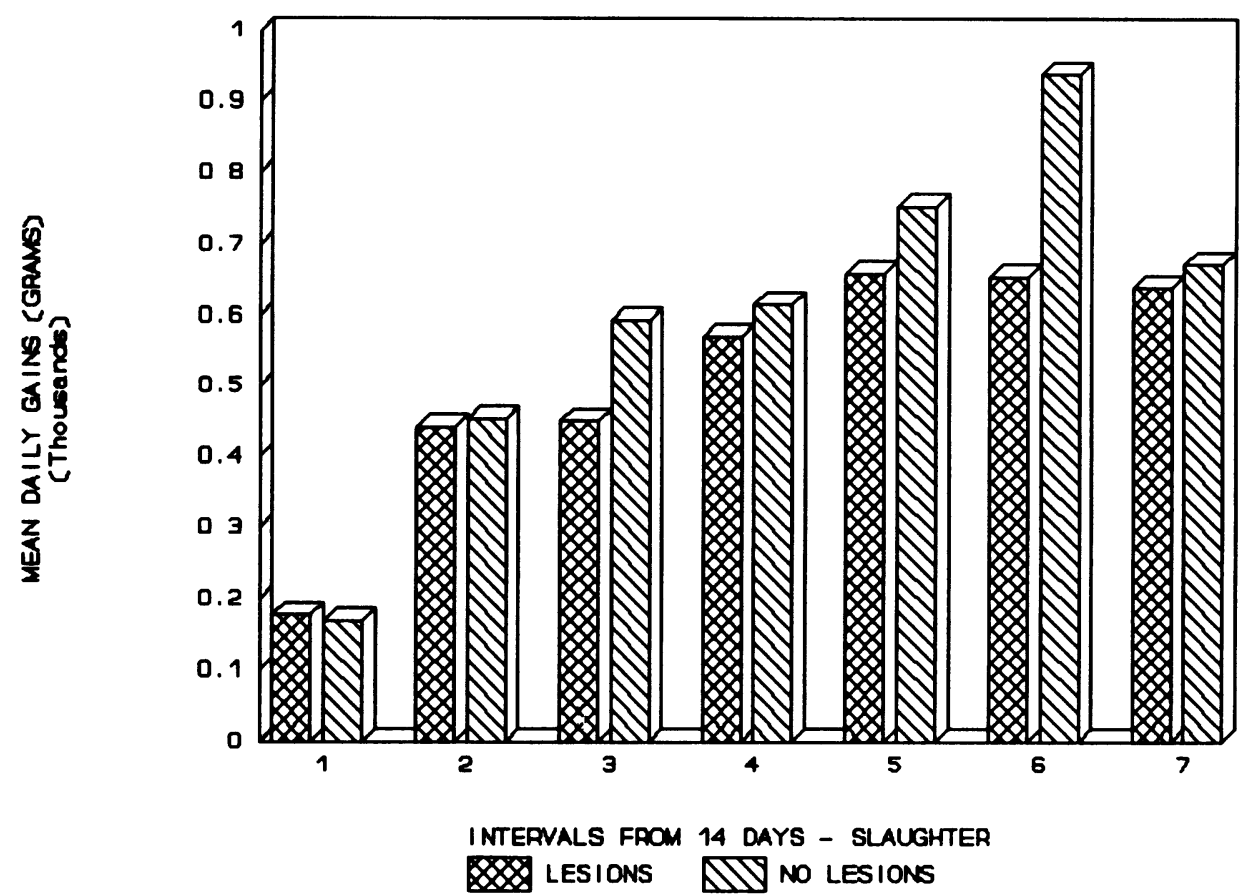

Figure 2. This graph compares the recorded mean daily gains of the pigs in Herd B with those estımated had there been no lesion effects. The estımated mean daily gains were the intercepts when the herd mean daily gain for each interval was regressed against the lesions present at slaughter.

creased daily gains and dorso-caudal pleuritis (CPDC) with increased daily gains $(p=0.0036)$. The total estimated change in daily gain was -16 grams $(4.3 \%)$. The $R^{2}$ of the model was 0.011 .

During the third interval, 56-77 days, the combined lesions were associated with a reduction in mean daily gain of 36 grams (7.1\%). Moderate fissures, FISS-2, $(\mathrm{p}=0.013)$ and severe atrophic rhinitis, $\mathrm{AR}=3$, $(\mathrm{p}=0.0248)$, moderate atrophic rhinitis, $\mathrm{AR}=2$ $(\mathrm{p}=0.045)$ and parietal pleuritis $(\mathrm{P}=0.0412)$ contributed to the reduction. Dorso-caudal pleuritis was associated with increased daily gains $(\mathrm{p}=0.0412)$. The $\mathrm{R}^{2}$ of the model was 0.076 .

During the fourth interval, 77-98 days, fissures $(\mathrm{p}=0.0158)$ and pericarditis $(\mathrm{p}=0.0365)$ were associated with a reduction in mean daily gain of $14 \mathrm{~g}(2.9 \%), \mathrm{R}^{2}=0.036$.

During the fifth interval, 98-119 days, anterioventral pleuritis $(p=0.0128)$ and interaction between Mycoplasma-like pneumonia (MPLP) and dorso-caudal pleuritis $(\mathrm{p}=0.0058)$ were associated with a reduction in mean daily gains. The main effects of Mycoplasma-like pneumonia $(\mathrm{p}=0.0017)$ and dorso-caudal pleuritis $(\mathrm{p}=0.239)$ were asso- 
ciated with higher daily gains. Interaction between anterio-ventral and dorso-caudal pleuritis was associated with higher daily gains ( $\mathrm{p}=0.034)$. The net effect of these lesions was $a+3 g(0.45 \%)$ but the $R^{2}$ of the equation was only 0.011 .

During the sixth interval, 119-140 days, the lesions were associated with a reduction in mean daily gain of $82 \mathrm{~g} \mathrm{(9.2 \% ).} \mathrm{Anterio-ven-}$ tral pleuritis $(\mathrm{p}=0.0334), \mathrm{AR}=3 \quad(\mathrm{p}=0.0146)$, $A R=2 \quad(p=0.0003), A R=1 \quad(p=0.0005)$ were main effects that contributed to the reduction. Complicated pneumonia, COMP, $(\mathrm{p}=0.0186)$ and dorso-caudal pleuritis $(\mathrm{p}=0.0046)$ main effects were associated with higher daily gains. The interaction between anterio-ventral pleuritis and complicated pneumonia ( $p=0.0085$ ) was negative. The $R^{2}$ of this equation was 0.106 .

During the 7th or last interval, 140 days until slaughter, the lesions were associated with a reduction in mean daily gain of $14 \mathrm{~g}(2.0 \%)$. Mycoplasma-like pneumonia $(\mathrm{p}=0.0084)$ was the only main effect that reduced mean daily gains but the interaction between Mycoplasma-like pneumonia and complicated pneumonia $(\mathrm{p}=0.0008)$ was also a negative factor. The main effect of complicated pneumonia was positive but not significant $(\mathrm{p}=0.7023)$. Sex (male/castrate) was associated with greater mean daily gains during this interval ( $\mathrm{p}=0.0019)$. The $\mathrm{R}^{2}$ of this equation was 0.259 . The parameter estimates of the final regression models for the 7 intervals in herd $\mathrm{A}$ are shown in Table $2 \mathrm{~A}$.

\section{Herd B}

In Herd B, Mycoplasma pneumonia $(\mathrm{p}=0.0157)$ and sub-acute/chronic pleuropneumonia, PLPN-C, $(\mathrm{p}=0.0003)$ were associated with higher daily gains of $8 \mathrm{~g}(4.73 \%)$ during the first interval. The $\mathrm{R}^{2}$ of this equation was 0.043 .
During the second interval, anterio-ventral pleuritis $(\mathrm{p}=0.0001)$ was associated with decreased and severe fissures increased daily gains $(\mathrm{p}=0.0036)$. The total estimated change in daily gain was $-11 \mathrm{~g}(2.4 \%)$. The $\mathrm{R}^{2}$ of this equation was 0.072 .

During the third interval, the combined lesions were associated with a reduction in mean daily gain of $144 \mathrm{~g}(24.2 \%)$. Atrophic rhinitis, grades 1-3 $(\mathrm{p}=0.0104,0.0040$ and 0.0025 , respectively), anterio-ventral pleuritis $(\mathrm{p}=0.0218)$ and pericarditis, PERC, $(\mathrm{p}=$ 0.0001 ) were main effects that significantly reduced daily gains during this interval. Severe fissures, FISS-3, $(\mathrm{p}=0.0021)$ were associated with higher daily gains. The $R^{2}$ of the equation was 0.148 .

During the fourth interval, the lesions were associated with a reduction in mean daily gain of $45 \mathrm{~g}$ (7.3\%). Moderate fissures, FISS-2, $(\mathrm{p}=0.0137)$, pericarditis $(\mathrm{p}=0.0001)$ and $\mathrm{AR}=3$ $(p=0.0014)$ contributed to the reduction. The $\mathrm{R}^{2}$ of the equation was 0.125 .

During the fifth interval, the lesions were associated with a reduction in mean daily gain of $94 \mathrm{~g}(12.5 \%)$. Mycoplasma-like pneumonia $(\mathrm{p}=0.0001)$, dorso-caudal pleuritis $(\mathrm{p}=0.0278)$ and $A R=3(p=0.0378)$ were the main effects that were associated with decreased mean daily gains. During this interval there were many statistically significant interactions between lesions. Fissures $\times$ anterio-ventral pleuritis $(\mathrm{p}=0.0218)$, pericarditis $\times \mathrm{AR}=3(\mathrm{p}=$ $0.0013)$ and anterio-ventral pleuritis $\times$ parietal pleuritis $(\mathrm{p}=0.0257)$ contributed to the reductions in mean daily gains. Dorso-caudal pleuritis $\times$ anterio-ventral pleuritis $(\mathrm{p}=0.0134)$, dorso-caudal pleuritis $\times$ parietal pleuritis $(p=0.0176)$ and Mycoplasma-like pneumonia $x$ anterio-ventral pleuritis $(\mathrm{p}=0.0234)$ were associated with increased gains. The main effects of anterio-ventral pleuritis, parietal pleuritis, pericarditis and fissures were not 
Table 2A. Parameter estimates for coefficients in the final model for each growth interval in herd A.

\begin{tabular}{|c|c|c|c|c|c|c|c|c|}
\hline Interval & (1) & 1 & 2 & 3 & 4 & 5 & 6 & 7 \\
\hline \multicolumn{2}{|l|}{ Intercept: } & $174.0^{* * *}$ & $348.6 * * *$ & $505.2 * * *$ & $476.4 * * *$ & $655.0^{* * *}$ & $888.7 * * *$ & $692.3^{* * *}$ \\
\hline \multicolumn{9}{|l|}{ Main effects: } \\
\hline & $\mathrm{S}$ & - & - & - & - & - & $49.5^{* *}$ & - \\
\hline \multicolumn{9}{|l|}{ Atrophic } \\
\hline \multirow[t]{3}{*}{ rhinitis } & $\mathrm{AR}=1$ & - & - & - & - & - & $-105.1 * * *$ & - \\
\hline & $A R=2$ & - & - & $-38.9 *$ & - & - & $-114.4 * * *$ & - \\
\hline & $\mathrm{AR}=3$ & - & - & $-88.0^{*}$ & - & - & $-129.8^{*}$ & - \\
\hline \multirow[t]{3}{*}{ Pneumonia } & MPLP\% & - & - & - & - & $5.7 * *$ & - & $-8.4 * * *$ \\
\hline & COMP\% & - & - & - & - & - & $34.4^{*}$ & $2.9^{\mathrm{ns}}$ \\
\hline & PLPN-C & - & - & - & - & - & - & - \\
\hline \multirow[t]{3}{*}{ Pleuritis: } & CPAV\% & - & $-6.3^{*}$ & - & - & $-12.8 * * *$ & $-60.2^{*}$ & - \\
\hline & CPDC\% & - & $2.1^{*}$ & $3.6^{*}$ & - & $2.9^{\text {ns }}$ & $4.6^{*}$ & - \\
\hline & CPPL & - & $-24.2^{*}$ & $-51.8^{*}$ & - & - & - & - \\
\hline \multicolumn{9}{|l|}{ Interlobular } \\
\hline \multirow[t]{2}{*}{ scarring } & FISS=2 & - & - & $-63.3^{*}$ & $-66.7^{*}$ & - & - & - \\
\hline & $\mathrm{FISS}=3$ & - & - & - & - & - & - & - \\
\hline Pericarditis & PERC & - & - & - & $-96.3^{*}$ & - & - & - \\
\hline \multicolumn{9}{|l|}{ Interactions: } \\
\hline \multirow{3}{*}{\multicolumn{2}{|c|}{$\begin{array}{l}\text { MPLP\%×COMP\% } \\
\text { MPLP } \% \times C P A V \% \\
\text { MPLP } \% \times C P D C \%\end{array}$}} & - & - & - & - & - & - & $-4.9 * * *$ \\
\hline & & - & - & - & - & - & - & - \\
\hline & & - & - & - & - & $-0.9 * *$ & - & - \\
\hline \multicolumn{2}{|c|}{ CPAV\%×COMP\% } & - & - & - & - & - & $-12.9 * *$ & - \\
\hline \multicolumn{2}{|c|}{ CPAV\% $\%$ FISS-2 } & - & - & - & - & - & - & - \\
\hline \multicolumn{2}{|c|}{ CPAV\% $\%$ CPDC $\%$} & - & - & - & - & $0.5^{*}$ & - & - \\
\hline \multicolumn{2}{|c|}{ CPPL $\times$ CPAV\% } & - & - & - & - & - & - & - \\
\hline \multicolumn{2}{|c|}{ CPPL×PDC\% } & - & - & - & - & - & - & - \\
\hline \multicolumn{2}{|c|}{ PERC $\times A R=3$} & - & - & - & - & - & - & - \\
\hline \multicolumn{2}{|l|}{$\mathbf{R}^{2}$} & 0.000 & 0.011 & 0.076 & 0.036 & 0.011 & 0.106 & 0.259 \\
\hline \multicolumn{2}{|c|}{$\mathrm{MDG}_{1}$ - INTERCEPT } & 0 & $-16 \mathrm{~g}$ & $-36 \mathrm{~g}$ & $-14 \mathrm{~g}$ & $+3 \mathrm{~g}$ & $-82 \mathrm{~g}$ & $-14 \mathrm{~g}$ \\
\hline
\end{tabular}

$* * * \mathrm{p}<0.001 ; * * 0.01<\mathrm{p} 0.001 ; * 005<\mathrm{p} \leq 0.01)$.

$\mathrm{S}=$ sex, $\mathrm{AR}=$ Atrophic rhınitis, MPLP=Mycoplasma-like pneumonia, $\mathrm{COMP}=\mathrm{Complicated} \mathrm{pneumonı,} \mathrm{PLPN}-$ $\mathrm{C}=$ subacute/chronic pleuro-pneumonia, $\mathrm{CPDC}=$ Dorso-caudal pleuritıs, CPAV=Anterio-ventral pleuritıs, CPPL=Chronic parietal pleuritis, FISS=Fissures, $\mathrm{PERC}=$ Pericarditis.

All variables included in significant interactions were forced into the final model as main effects. Significance levels are indicated by asterisks. (NS: not significant).

significant. The $R^{2}$ of the equation was 0.22 . During the sixth interval, the lesions were associated with an estimated reduction in mean daily gain of $283 \mathrm{~g}(30.9 \%)$. Mycoplasma-like pneumonia ( $\mathrm{p}=0.0001)$, complicated pneumonia $(\mathrm{p}=0.033)$, dorso-caudal pleuritis $(\mathrm{p}=$ $0.0235)$, anterio-ventral pleuritis $(\mathrm{p}=0.0001)$,
$\mathrm{AR}=3(\mathrm{p}=0.0001), \mathrm{AR}=2(\mathrm{p}=0.0013), \mathrm{AR}=1$ $(p=0.0062)$ and FISS-2 $(p=0.0170)$ as main effects contributed to the reduction. In contrast, dorso-caudal pleuritis $\times$ anterio-ventral pleuritis $(p=0.0001)$ were associated with increased daily gains. The $R^{2}$ of the equation was 0.25 . During the last interval, 140 days until slaugh- 
Table 2B. Parameter estımates for coefficients in the final model for each growth interval in herd B.

\begin{tabular}{|c|c|c|c|c|c|c|c|c|}
\hline Interval & (1) & 1 & 2 & 3 & 4 & 5 & 6 & 7 \\
\hline Intercept: & & $169.4 * * *$ & $452.2^{* * *}$ & $594.7 * * *$ & $616.4 * * *$ & $754.0^{* * *}$ & $937.1 * * *$ & $6717 * * *$ \\
\hline \multicolumn{9}{|l|}{ Main effects: } \\
\hline Sex & $\mathrm{S}$ & - & - & - & - & - & - & - \\
\hline \multicolumn{9}{|l|}{ Atrophic } \\
\hline \multirow[t]{3}{*}{ rhınıtis } & $\mathrm{AR}=1$ & - & - & $-1223^{*}$ & - & - & $-174.9 * *$ & - \\
\hline & $\mathrm{AR}=2$ & - & - & $-136.7 * *$ & - & - & $-2048^{* *}$ & - \\
\hline & $\mathrm{AR}=3$ & - & - & $-151.9 * *$ & $-84.4 * *$ & $-67.4 *$ & $-261.7 * * *$ & - \\
\hline \multirow[t]{3}{*}{ Pneumonia } & MPLP\% & - & - & - & - & $5.7^{* *}$ & - & $-84 * * *$ \\
\hline & COMP\% & - & - & - & - & - & $-8.2^{*}$ & $-94^{* *}$ \\
\hline & PLPN-C & $14.8^{* * *}$ & - & - & - & - & - & - \\
\hline \multirow[t]{3}{*}{ Pleuritis: } & CPAV\% & - & $-3.1 * * *$ & $-3.6^{*}$ & - & $-8.4^{*}$ & $-10.8^{* * *}$ & - \\
\hline & CPDC\% & - & - & - & - & $29^{\text {ns }}$ & $-4.3^{*}$ & - \\
\hline & CPPL & - & - & - & - & $-363^{\text {ns }}$ & - & - \\
\hline \multirow{3}{*}{$\begin{array}{l}\text { Interlobular } \\
\text { scarring }\end{array}$} & & & & & & & & \\
\hline & FISS $=2$ & - & - & - & $-52.3^{*}$ & $4.6^{\mathrm{ns}}$ & $-53.4^{*}$ & - \\
\hline & FISS $=3$ & - & $809 * *$ & $92.6^{* *}$ & - & - & - & - \\
\hline Pericarditıs & PERC & - & - & $-117.4^{* * *}$ & $-125.0^{* * *}$ & $44.2^{\text {ns }}$ & - & - \\
\hline \multicolumn{9}{|l|}{ Interactions } \\
\hline \multicolumn{2}{|c|}{ MPLP\%×COMP\% } & - & - & - & - & - & - & - \\
\hline \multicolumn{2}{|c|}{ MPLP\%×CPAV\% } & - & - & - & - & $0.8^{*}$ & - & - \\
\hline \multicolumn{2}{|c|}{ MPLP $\% \times C P D C \%$} & - & - & - & - & $-0.9 * *$ & - & - \\
\hline \multicolumn{2}{|c|}{ CPAV\% $\%$ COMP\% } & - & - & - & - & - & - & - \\
\hline \multirow{2}{*}{\multicolumn{2}{|c|}{$\begin{array}{l}\text { CPAV } \% \times \text { FISS }-2 \\
\text { CPAV } \% \times \text { CPDC } \%\end{array}$}} & - & - & - & - & $-11.5^{*}$ & - & - \\
\hline & & - & - & - & - & $0.1^{*}$ & $0.1 * * *$ & - \\
\hline \multicolumn{2}{|c|}{ CPPL $\times$ CPAV $\%$} & - & - & - & - & $-13.7^{*}$ & - & - \\
\hline \multicolumn{2}{|c|}{ CPPL×PDC\% } & - & - & - & - & $-11.1^{*}$ & - & - \\
\hline \multicolumn{2}{|c|}{$\mathrm{PERC} \times \mathrm{AR}=3$} & - & - & - & - & $-261.6 * *$ & - & - \\
\hline \multicolumn{2}{|l|}{$\mathbf{R}^{2}$} & 0.043 & 0.072 & 0.148 & 0.125 & 0220 & 0.250 & 0.077 \\
\hline \multicolumn{2}{|c|}{$\mathrm{MDG}_{1}-\mathrm{INTERCEPT}$} & 0 & $-11 \mathrm{~g}$ & $-144 \mathrm{~g}$ & $-45 \mathrm{~g}$ & $-94 \mathrm{~g}$ & $-283 \mathrm{~g}$ & $-32 \mathrm{~g}$ \\
\hline
\end{tabular}

For abbreviatıons see Table 2A.

ter, the lesions were associated with a reduction in mean daily gain of $32 \mathrm{~g}(4.6 \%)$. Mycoplasma-like pneumonia $(\mathrm{p}=0.0001)$ and complicated pneumonia $(\mathrm{p}=0.0044)$ were the only lesions that significantly contributed to a reduction in weight gain during the last interval. The $\mathrm{R}^{2}$ of this equation was 0.077 . The parameter estimates of the final regression models for the 7 intervals in herd B are shown in Table 2B.

\section{Discussion}

Paisley et al. (1993) reported that Mycoplasma pneumonia, complicated pneumonia, anterio-ventral pleuritis, fissures, and atrophic rhinitis significantly decreased mean daily gains over the entire growth period in the same study herds. The total impact on mean daily gain of the diseases under study during the interval from 14 days until slaughter (MEANDG) was estimated to be a reduc- 
tion of 27 and $98 \mathrm{~g}$ per day in Herd A and B, respectively. Reductions in mean daily gains during the interval from the fourth weighing until slaughter (MDG25) were $31 \mathrm{~g}$ in Herd A and $137 \mathrm{~g}$ in Herd $\mathrm{B}$. The lesions were associated with increased ages at slaughter of 2 days and 16.7 days in the respective herds.

To estimate the effects of the lesions on mean daily gains during the 6,21 day intervals and the variable interval between the seventh weighing and slaughter mean daily gains for each interval were regressed against the lesions. These comparisons suggest a chronology for the onset of the diseases and development of the lesions and may explain some differences in response by the pigs from the 2 different herds.

The results of regressing mean daily gains against the lesions in Herd A suggest the following scenario. During the period from 14 to 56 days the pigs were weaned (median age, 27 days) and were in controlled environment housing. Before leaving the controlled environment housing the pigs contracted the infections that resulted in anterio-ventral pleuritis, pericarditis, fissures and atrophic rhinitis. These lesions were associated with statistically significant, but very small, reductions in mean daily gains while the pigs were in the controlled housing. During Interval 2, at a median age of 47 days, the pigs were moved from the controlled environment housing to the growing barns and remained there until Interval 4. At approximately 90 days of age they were moved to the finishing barns. Mean daily gains during Interval 4 were $7 \mathrm{~g}$ less than in Interval 3. Much of the reduction in mean daily gain was likely due to factors associated with being moved because the decline occurred in both pigs with and pigs without lesions. In addition, moderate fissures and pericarditis, the 2 lesions that were significantly associated with reduced mean daily gains dur- ing that interval, affected only $13.6 \%$ and $4 \%$ of the pigs, respectively. Further, the $\mathrm{R}^{2}$ of the regression model for this interval was 0.036 indicating that these lesions explained only $3.6 \%$ of the variation in weight gain during that interval.

Anterio-ventral pleuritis and atrophic rhinitis were the lesions most associated with reduced mean daily gains during the period from approximately 90 days of age until 140 days. The effects were greatest ( $-82 \mathrm{~g}$ per day, $9.2 \%)$ during the Interval $6,120-140$ days, 3 to 6 weeks after the pigs entered the finishing barns. Mycoplasma-like pneumonia was not a significant explanatory variable until the last interval, 140 days until slaughter. The daily gains were reduced approximately $14 \mathrm{~g}$ during the last interval before slaughter.

The suggested scenario for Herd B is somewhat similar. It also appears that the pigs contracted the diseases that caused anterio-ventral pleuritis and fissures, and possibly, atrophic rhinitis before they left the controlled environment housing. At a median age of 67 days (Interval 3) the pigs were moved from the controlled environment housing to the growing barn. Major reductions in mean daily gains of $144(22.4 \%)$ and $45 \mathrm{~g}(7.3 \%)$ associated primarily with anterio-ventral pleuritis, pericarditis and atrophic rhinitis occurred in the third and fourth intervals, respectively. The associated effects of Mycoplasma pneumonia, dorso-caudal pleuritis and parietal pleuritis were first apparent during the Interval 5, 98-119 days, about 3 weeks after the first contact with older pigs. The effects of the combined lesions were greatest $(-283 \mathrm{~g}$, $30.2 \%$ ) during the Interval $6,119-140$ days. The pigs were moved to the finishing barn at a median age of 121 days.

In both herds, anterio-ventral pleuritis was associated with reduced mean daily gains during the second interval and the most of the study 
period. Pericarditis was important during the third and fourth intervals. Negative effects of atrophic rhinitis were first shown in the third interval and continued through the sixth. The negative effects of moderate fissures appeared in the fourth interval. Reductions associated with dorso-caudal pleuritis began during the fifth interval, 98-119 days and lasted about 6 weeks. In Herd B, the reductions associated with Mycoplasma-like pneumonia were first demonstrated at approximately 98-119 days of age but in Herd A no effect was demonstrated until the last interval, 140 days until slaughter. Complicated pneumonia had it's negative main effect and interactions during the last 2 intervals.

These findings suggest that anterio-ventral pleuritis, pericarditis and fissures have etiologies or predisposing factors unrelated to $\mathrm{My}$ coplasma or Actinobacillus pleuropneumonia infections. These lesions were associated with significant reductions in mean daily gains earlier and for longer times during the growth period than were the lesions commonly associated with those 2 agents. Chronic pleuritis has also been associated with Mycoplasma hyorhinis, Haemophilus parasuis and Pasteurella multocida and Influenza suis infections (Willeberg et al. 1982, Pijoan \& Fuentes 1987, Mousing et al. 1989, Falk et al. 1991). It has been reported that fissures were a common finding in pigs that had recovered from Mycoplasma pneumonia (Bertschinger 1972) and catarrhal or catarrhal/purulent pneumonia (Christensen 1991). This is in agreement with the results of this study where fissures at slaughter were associated with early reduced growth rate, while mycoplasma pneumonia at slaughter was associated with reduced growth rate in the period close to the time of slaughter.

Only Mycoplasma-like and complicated pneumonia had negative associations with mean daily gains during the last period from 140 days until slaughter. This suggests that the pigs had recovered from the other diseases and growth was not adversely affected by the presence of the other lesions. There was other evidence of recovery from the effects of the lesions and sometimes compensatory weight gains. It was common for a lesion to be associated with significantly lower gains during 1 or 2 intervals followed by insignificant or increased gains during later intervals. Herd B pigs with dorso-caudal pleuritis gained equal to or faster than non-affected pigs during all intervals except the 2 intervals between 77 and 119 days. The estimated reductions in mean daily gains associated with Mycoplasma-like pneumonia decreased from $59 \mathrm{~g}$ during the fifth interval to $33 \mathrm{~g}$ during the last interval in Herd B. The pigs in Herd A first showed reduced gains associated with Mycoplasma-like pneumonia in the interval from 140 days until slaughter and did not show recovery before slaughter.

It is likely that factors other than the lesions had a greater effect on herd mean daily gains than the lesions. For example, in Herd A, mean daily gain during Interval 7 was $22.2 \%$ less than in interval 6 in the no-lesion group. The mean daily gain in the group with lesions was only $16 \%$ less in the seventh interval than in the sixth. In Herd B, mean daily gain in the no-lesion group during interval 7 was $32.6 \%$ less than in interval 6 . The mean daily gain in the group with lesions was only $2.1 \%$ less in the seventh interval than in the sixth. In the group with lesions, mean daily gain increased $121 \mathrm{~g}, 26.8 \%$, in interval 4 compared to interval 3, while in the pigs with no lesions the increase between the same intervals was only 21 g, $3.7 \%$.

These observations suggest the following explanation. Depressed feed and water intake are common in pigs with respiratory diseases 
or other febrile periods (Pointon et al. 1985, Pijpers et al. 1990). When feed and water intake are depressed so are daily weight gains. If no change in the amount of feed per pen was made during periods of illness the healthy pigs may have been fed to excess and, as a result, had normal or higher than normal daily gains. As the diseased pigs regained their appetites their daily gains increased but, simultaneously, the amount of excess feed available for the healthy pigs decreased, along with their rates of gain. Limited or restricted feeding during the later parts of the finishing period is common in Denmark in order to decrease daily gains and increase the lean meat percentage of the carcasses. Limited feeding may have reduced the difference in rates of weight gain in diseased versus non-diseased pigs by limiting the weight gains in the non-diseased pigs more than that of diseased pigs, especially during the last interval.

Chronic pleuritis was of major interest in this study because it is thought to cause significant reductions in growth rates in Danish swine (Christensen 1982, Christensen 1984). However, Paisley et al. (1993) reported that dorsocaudal pleuritis was associated with significantly higher mean daily gains in 1 of 2 study herds but no significant effect in the other. $\mathrm{Pa}$ rietal pleuritis lacked significant association with mean daily gains in either herd, when the appearance of parietal pleuritis was controlled for the presence of other lesions. Parietal pleuritis was often associated with anterio-ventral or dorso-caudal pleuritis or both.

In this study, in Herd A, parietal pleuritis was a significant explanatory variable for reduced mean daily gain only during Interval 2 and during Interval 3. Dorso-caudal pleuritis, as a significant main effect, was always associated with higher mean daily gains.

Herd B pigs with parietal pleuritis and anterio-ventral pleuritis had reduced mean daily gains during the fifth interval. Those with parietal pleuritis and dorso-caudal pleuritis had increased mean daily gains during the same interval. Pigs with dorso-caudal pleuritis had reduced daily gains while those with dorsocaudal pleuritis and anterio-ventral pleuritis had increased daily gains. The main effects of parietal pleuritis and anterio-ventral pleuritis were insignificant during the interval 5. During interval 6 both dorso-caudal pleuritis and anterio-ventral pleuritis, as main effects, were associated with decreased mean daily gain but the interaction between the 2 resulted in higher daily gains. Anterio-ventral pleuritis was a significant explanatory variable associated with reduced mean daily gains during several specific intervals of the growth period, as well as the entire growth period (Paisley et al. 1993), in both herds. Although associated with differences (positive or negative) in mean daily gains during some intervals, dorso-caudal pleuritis and parietal pleuritis did not have a negative effect on mean daily gains over the entire growth period. Pleuritis confined to the dorso-caudal lobes is primarily associated with Actinobacillus pleuropneumoniae infections (Nielsen \& Mandrup 1977, Christensen 1981, Friendship et al. 1984, Derosiers \& Moore 1986, Saunders et al. 1981, Mousing et al. 1989). Anterio-ventral pleuritis is not reported as a common sequela to Actinobacillus pleuropneumoniae infections but is often associated with lesions such as pericarditis and complicated pneumonia.

Mycoplasma-like pneumonia, complicated pneumonia, anterio-ventral pleuritis, pericarditis, fissures and atrophic rhinitis, separately and through interactions with other lesions, significantly reduced mean daily gains during some specific parts of the growth period as well as the entire growth period. These diseases warrant more attention than Actinobacillus infections regarding their effects on 
growth rates in these 2 herds. Reductions in mean daily gains associated with atrophic rhinitis were significant although the sows in both herds were vaccinated to prevent atrophic rhinitis.

Two possible sources of bias may affect the results. First, as the slaughter age differed for the pigs, time for recovery for early lesions differed too. Thus the pigs with the lowest daily gain had the longest time for recovery of lesions. Secondly, performing multiple tests on the same data, rise the question of multiple equation bias, because if enough significance tests are done, some of the effects may be significant by chance alone (Friedman et al. 1985).

Keeping these possible biases in mind, the conclusions of the study is, that the impact of the lesions on mean daily gains over the entire growth period in the 2 herds were different due in part to the different times when the diseases exerted their effects and partly to compensatory growth following recovery from the diseases. These observations are in partial agreement with Noyes et al. (1990) who reported that lesions present at slaughter are not a good indicator of the lifetime pneumonia history of an animal. However, by studying the associations between the lesions and mean daily gains over relatively short intervals during the growth period a clearer picture of the history and effects of the diseases was obtained.

\section{Acknowledgements}

This manuscript is dedicated to Prof. Dr. Med. Vet. Ole Aalund who passed away before completion of the study. The authors thank The Federation of Danish Pig Producers and Slaughter Houses and The Danısh Agricultural and Veterınary Research Councll for the financial support for this project.

\section{References}

Aalund $O$, Willeberg $P$, Mandrup M, Rıemann HP: Lung Lesions at Slaughter: Associations to Factors in the Pig Herd. Nord. Vet -Med. 1976, 28, 487-495.

Baalsrud KJ. The Effect of Atrophic Rhinitis on Growth Rate. Acta Vet. Scand 1987, 28, 299304.

Bertschinger HU, Keller $H$, Lohrer A, Wegman $W \cdot$ Der zeitliche Verlauf der experımentellen enzootischen Pneumonie biem SPF-Schwein. Schwe1z Arch. Tierheilk., 1972, 114, 107-118.

Backstrom L, Hoefling DC, Morkoc AC, et al : Effect of Atrophic Rhınıtıs on Growth Rate in Illinois Swine Herds. J. Amer. Vet. Med. Assoc. 1987, 187, 712-715

Christensen $G$. Pleuropneumoni hos svin fremkaldt af Haemophilus pleuropneumoniae s parahaemolyticus III: Observationer vedr. klınısk manIfestatıon på besætnıngsplan samt terapeutıske og immunprofylaktıske mulıgheder. (Pleuropneumonia in swine caused by Haemophilus pleuropneumoniae s. parahaemolyticus.II. Studies on the clinical manifestations in herds, treatment and control by vaccination). Nord. Vet.-Med. 1982, 34, 113-123.

Christensen $G$ USK (Udvidet SygsdomsKontrol) og den praktiserende dyrlæge. Dansk. (Extended disease examinations and the practicing veterınarian). Vet Tidsskr. 1991, 74, 249-252.

Collıns MT, Backstrom LR, Brim TR ' Turbınate Perimeter Ratio as an Indicator of Conchal Atrophy for Diagnosis of Atrophic Rhinitis in Pigs. Amer. J. vet. Res. 1989, 150, 421-424.

Cowart RP, Lipsey RJ, Hedrick HB · Measurement of Conchal Atrophy and Pneumonic Lesions and Their Association with Growth Rate in Commıngled Feeder Pigs. J Amer. vet. med. Assoc. 1990, 196, 1262-1264.

Dybkjar L, Vraa-Andersen L, Paisley LG, Møller K, Christensen G, Agger JF: Associations between behavior and stomach lesions in slaughter pigs. Prev. vet med, (In press.)

Desrosiers $R$, Moore C A Review of Some Aspects of Porcine Pleuropneumonia. Proceedings, Amer. Ass. Swine Pract., Minneapolıs, 1986, 495511

Frledman LM, Furberg CD, DeMets DL. Fundamentals of clinical trials. PSG PUBLISHING COMPANY, INC. 1985. 256 p.

Friendship RM, Hacker R, McMıllan I, Pıeper SS, Swaminathan S, Takov $R$, Wilson MR: Hae- 
mophilus Pleuropneumonia: Effect on Growth Rate and Related Parameters in Naturally Occurring Disease. Proceedings, Int. Pig vet. Soc., Ghent, 1984, 97.

Kjeldsen $N$, Nielsen $H$, Pedersen $B \cdot$ Bestemmelser af slagtesvindets st $\varnothing$ rrelse hos renracede svin og hos krydsningssvin. (Determination of the size (liveweight) of purebred and crossbred slaughter swine). Danske Slagterier internal report. 1990.

Lindqvist $\mathrm{JO}$. Animal Health and Environment in the Production of Fattening Pigs. A study of disease incidence in relation to certain environmental factors, daily weight gain and carcass classifıcatıon. Acta Vet Scand. 1974, suppl. 51, 1-78.

Love RJ, Wilson MR, Tasler G: Porcine Atrophic Rhınitıs. Australıan vet. J. 1985, 62, 377-378.

Mousing J, Lybye H, Barfod K, Meyling A, Rønsholt $L$, Willeberg $P$. Chronic pleurisy in pigs for slaughter: An epidemiological study of infectious and rearıng-system related risk factors. Prev. Vet. Med. 1989, 9, 107-119.

Nielsen R, Mandrup M: Pleuropneumonia in swine caused by Haemophilus Parahalmolytıcus. Nord. Vet.-Med. 1977, 29, 465-473

Noyes EP, Feeny DA, Pljoan C: Comparison of the effect of pneumonia detected during the lifetıme with pneumonia detected at slaughter on growth in swine. J. Amer. vet. med. Assoc. 1990, 197, 1025-1029.

Paisley LG. A prospective study of the economic impact of chronic pleuritis and other respiratory diseases in two conventional danish swine herds. Thesis, 1991, Copenhagen, 41-43; 67-70.

Paisley LG, Vraa-Andersen L, Dybkjar L, Møller K, Christensen G, Mousing J, Agger JF: An epidemiological and economic study of respiratory disease in two conventional danish swine herds: Prevalence of respiratory lesions at slaughter and their effects on growth. Acta vet. cand 1993, 34, 319-329.

Pedersen KB, Barfod $K$ : The aethiological significance of Bordetella bronchiseptica and Pasturella multocida in atrophic rhinitis of swine. Nord. Vet.-Med. 1981, 33, 513-522.

Pljoan C, Fuentes $M$ : Severe pleuritis associated with certain strains of pasteurella multocida in swine. J. Amer. vet. med. Assoc., 1987, 191, 823-826.

Pupers A, Vernooy JACM, van Leengoed $L A M G$, Verheyden JHM: Feed and water consumption in pigs following an Actınobacillus Pleuropneumonıa challenge. Proceedıngs. Int. Pig Vet. Soc., Lausanne, 1990, 39.
Pointon AM, Byrt D, Heap P: Effect of enzootic pneumonia of pigs on growth performance. Austr. vet. J. 1985, 62, 13-18.

Rasmussen JF. The Economic Importance of Chronic Pleuritıs in Pig Production. Proceedings, Int. Pig Vet. Soc., Ghent, 1984, 347.

Ross $R F \cdot$ Chronic pneumonia of swine with emphasis on Mycoplasmal Pneumonia. Proceedings, Amer. Ass. Swıne Pract. Kansas City, 1984, 7996.

Saunders JR, Osborne AD, Sebunya JK. Preurmonıa in Saskatchewan swine: Abattoir incidences of intrathoracic lesions in pigs from a herd infected with Haemophilus pleuropneumonia and from other herds. Can. vet. J. 1981, 22, 244-247.

Statıstıcal Analysis System Inc · SAS User's Guide, 1979 Edition. Raleigh, NC, 391-396.

Scheit AB, Mayrose VB, Hill MA, Clark LK, Knox $K E$, Runnels LJ, Frantz $S$, Einstein $M E \cdot$ Relationship of growth performance to pneumonia and atrophic rhinitis detected at slaughter. J. Amer. vet. med. Assoc. 1990, 196, 881-884.

Straw BE, Burgl EJ, Hilley HP, Leman AD: Pneumonia and atrophic rhinitıs in pigs from a test station. J. Amer. vet. med. Assoc. 1983, 182, 607611.

Straw BE, Leman AD, Robinson RA: Pneumonia and atrophic rhinitis in pigs from a test station A Follow-up Study. J. Amer. vet. med. Assoc. 1985, 185, 1544-1546.

Straw BE, Tuovinen VK, Bigras-Poulın $M \cdot$ Estımation of the cost of pneumonia in swine herds. J. Amer. vet. med. Assoc. 1989, 195, 1702-1706.

Willeberg P, Gerbola M-A, Sanker SU, Kırkegaard Petersen $B$. Patologiske fund ved rutinemæssig og udvidet kødkontrol af slagtesvın. 2. Kødkontrollens diagnostıske værdı ved udpegning af mulige ætiologiske sygdomsenheder, specielt luftvejslidelser. (Pathological findıngs during routine and extended meat inspections of slaughter swine. 2. Diagnostic value of meat inspection findıngs in determining possible etıologies especially respiratory diseases). Dansk Vet. Tidsskr. 1982, 65, 712-721.

Wilson MR, Takov RM, Friendshıp RM, Martın SW, McMillan I, Hacker R, Swaminathan S: Prevalence of respiratory diseases and their association with growth rate and space in randomly selected swine herds. Can. J. vet. Res. 1986, 50, 209-216. 


\section{Sammendrag \\ En epıdimiologisk og фkonomisk unders $\emptyset$ gelse af luftvejslidelser 12 danske svinebesatninger: Sammen- hang mellem patologiske fund ved slagtning og gen- nemsnitlig daglig tilvakst $\mathrm{l}$ specifikke intervaller af vakstperioden.}

Ved anvendelse af regressions modeller indeholdende anden og tredje grads interaktioner kunne det påvises, at Mycoplasma-lignende pneumoni, kompliceret pneumonı, anterio-ventral pleuritis, fissurer og atrofisk rhinitis sıgnifikant nedsatte den gennemsnitlige daglige vækst $i$ specifikke vækstperioder $i$ både besætning $\mathrm{A}$ og $\mathrm{B}$. Det er sandsynligt, at perioderne med reduceret vækst afspejler perioder 1 hvilke lidelserne enten var på det akutte stade eller $\mathrm{i}$ begyndende bedring, fordi de ofte efterfulgtes af perioder med normal eller accelereret tilvækst. Den estimerede maksımale reduktion i daglig vækst associeret med kombinerede læsioner var 82 gram og 283 gram i henholdsvis besætning A og B i perıoden fra 120 til 140 dage. Selv om dorso-kaudal pleuritis og parietal pleuritis havde en lille negativ effekt $i$ to intervaller, havde ingen af dem dog signifikant negativ effekt på den totale vækstrate $\mathrm{i}$ hverken besætning $\mathrm{A}$ eller B (Paisley et. al. 1993). $\mathrm{R}^{2}$-værdierne fra regressions modellerne var mindre end 0,27 , hvilket viser, at lungelæsioner ved slagtning forklarede mindre end $27 \%$ af variationen i den gennemsnitlige daglige vækst $\mathrm{i}$ løbet af alle intervaller.

(Received May 1, 1992; accepted January 10, 1993).

Reprints may be requested from: J. F. Agger, Department of Animal Science and Anımal Health, Royal Veterinary and Agricultural University, Bulowsvej 13, DK-1870 Frederiksberg C, Denmark. 